\title{
Correction to: Distance estimation of howling golden jackals (Canis aureus) using relative sound level
}

\author{
Lukas Graf $^{1}\left[\right.$ (]) Jennifer Hatlauf ${ }^{1} \mathbb{C}$
}

Published online: 18 September 2021

(c) Mammal Research Institute, Polish Academy of Sciences, Bialowieza, Poland 2021

\section{Correction to: Mammal Research}

https://doi.org/10.1007/s13364-021-00587-2

In the original published version of this article, the authors' given name and family names were interchanged. The names are now correctly presented above.

The original article has been corrected.

Publisher's note Springer Nature remains neutral with regard to jurisdictional claims in published maps and institutional affiliations.

The original article can be found online at https://doi. org/10.1007/s13364-021-00587-2.

\section{Jennifer Hatlauf}

jennifer.hatlauf@boku.ac.at

1 Department of Integrative Biology and Biodiversity Research (DIB), Institute of Wildlife Biology and Game Management (IWJ), University of Natural Resources and Life Sciences (BOKU), Vienna, Austria 